\title{
Ameliorative effect of Allium atroviolaceum on sperm quality in cyclophosphamide- treated mice
}

\author{
Alireza Hosseini ${ }^{1}$, Mehrdad Shahrani', Shirin Asgharian', Maryam Anjomshoa², Ayoob Rostamzadeh³, \\ Zahra Lorigooini ${ }^{1 *}$, Najmeh Asgharzadeh ${ }^{1}$ and Abbas Azari ${ }^{1}$
}

\begin{abstract}
Background: Cyclophosphamide (CP) is an anti-neoplastic alkylating agent that is extensively used in different chemotherapy regimens. Adverse effects on the reproductive system, especially spermatogenesis, are one of the most important side effects of this drug. It is medically essential to use complementary and alternative drugs. Herbal drugs have long been used as a complementary treatment. Our purpose was to study the effect of hydroalcoholic Allium atroviolaceum L. extract on spermatogenesis in CP-treated mice.

Results: CP affected a significant decrease in sperm count, motility, viability, and morphology. Sperm count was significantly higher in the all extract groups than in the group of control $(p<0.001)$ and CP group $(p<0.001, p<0.01)$. Sperm motility was significantly greater in the extract $(100$ and $200 \mathrm{mg} / \mathrm{kg})$ groups than in the group of control $(p<$ 0.05 and $<0.001)$. Sperm immotility and rotational movement were significantly higher in the CP group than in the $\mathrm{CP}+$ extract groups $(p<0.001)$. The sperm viability was significantly greater in the $C P+$ extract $(200 \mathrm{mg} / \mathrm{kg})$ group than in the CP group $(p<0.001)$. The number of headless sperm, sperm with initial tail, with coiled tail, and sperm with curved body, was significantly lower in the CP+extract $(200 \mathrm{mg} / \mathrm{kg})$ group than in the CP group $(p<0.001)$.
\end{abstract}

Conclusion: A. atroviolaceum extract treatment significantly improved CP-induced reproductive toxicity.

Keywords: Allium atroviolaceum L., Infertility, Cyclophosphamide, Spermatogenesis

\section{Background}

Infertility refers to development of defect or disorder that prevents reproduction. Scientifically speaking, infertility refers to the inability to conceive after 12 months or more of ordered intercourse without the use of contraceptive methods. Infertility may occur due to various causes [1]. According to the available statistics, approximately $13 \%$ of couples are involuntarily childless in reproductive ages, with $35 \%$ of the cases due to male factors and $25 \%$ of them due to both male and female factors. Therefore, half of infertility cases are due to male factors [2]. The inability to produce sperm and ejaculate,

\footnotetext{
* Correspondence: zahralorigooini@gmail.com

${ }^{1}$ Medical Plants Research Center, Basic Health Sciences Institute, Shahrekord University of Medical Sciences, Shahrekord, Iran

Full list of author information is available at the end of the article
}

premature ejaculation, loss of libido, and the inability or unwillingness to have intercourse are certain reasons of infertility of male. However, the most cause of male infertility is the inadequate number of healthy and active sperm $[3,4]$. Normal semen samples should have a total sperm count of over 20,000,000 per mL, natural morphology of greater than $20 \%$, and progressive motility of greater than 50\% [5]. Certain drugs can also cause secondary infertility [6], including cyclophosphamide (CP). $\mathrm{CP}$ is a chemotherapy drug that is used to treat a wide variety of cancers. In addition to therapeutic applications, CP can cause adverse effects such as reproductive toxicity $[7,8]$. It has been demonstrated that $\mathrm{CP}$ leads to damage by disrupting tissue regenerative and excessively producing oxidative stress [9]. 
Complications, failures, and, in certain cases, heavy costs of medical treatments can be reduced by the use of complementary therapies. With the increasing detection of the side effects of chemical drugs in recent years, there has been widespread acceptance of medicinal plants for the treatment of certain diseases, especially infertility [10-13]. Therefore, there is an urgent need for further exploration of this area. The use of medicinal plants can have positive effects and has long been considered to increase fertility and to treat associated conditions such as hormonal imbalance, impotence (sexual weakness), oligospermia, low sperm motility, prostate inflammation, and varicocele. The effects of certain plants from the genus Allium to treat diseases such as infertility have been studied [14]. Allium cepa and Allium sativum are two of the plants whose effects on fertility and the reproductive system have been demonstrated [15]. The genus Allium consists of around 750 species. The species of this genus are rich in flavonoids, saponins, sapogenins, and volatile sulfur compounds [16, 17]. The antioxidant effects of these species have also been confirmed [18-20]. These plants have potent nutritional and therapeutic effects and have been used as traditional treatments for certain diseases since the past [21]. It has recently been determined that the plants from the genus Allium are effective on cardiovascular diseases, tumor geowth, and senescence, all of which seem to be associated with the effects of free radicals [22]. Broadleaf wild leek, botanically referred to as Allium atroviolaceum L., is a plant from the family Alliaceae and the genus Allium [23]. Regarding the optimal effects of other plants from this plant family on fertility, we conducted this research to study the effects of $A$. atroviolaceum on spermatogenesis in mouse.

\section{Methods \\ Extraction}

The aerial parts of $A$. atroviolaceum were collected from Sabzkouh heights between late May 2013 and late June 2013 and identified as the samples of interest by an expert botanist (herbarium no.: 801) at the Herbarium Unit of Medical Plants Research Center. Then, the samples were pulverized in an electric mill. Extraction was conducted by maceration. Briefly, the resulting powder was macerated in $70 \%$ ethanol. $72 \mathrm{~h}$ later, the resulting combination was filtered using filter paper of Whatman grade 1 and theresulting liquidwas concentrated in a rotary evaporator. Then, the obtainedextract was incubated at $37^{\circ} \mathrm{C}$ to dehydrate. The extract was stored in a freezer for future use. We diluted the extract to 50,100, and $200 \mathrm{mg} / \mathrm{kg}$ by dissolving it, in appropriate amounts, with normal saline [24].

\section{Animals}

This study was conducted with 64 male mice weighing $25-30 \mathrm{~g}$. The mice were bought from Razi Institute of Iran and then kept in the Animals House at $(23 \pm 2)^{\circ} \mathrm{C}$ under 12-h/12-h light-dark cycle, with ad libitum access to food and water. The mice were permitted to acclimate to their environment for 1 week before the beginning of the experiments. The mice were assessed for general health, and all steps of the study were implemented according to the rules of Guide for the Care and Use of Laboratory Animals of National Research Council Committee.

\section{Design of study}

In this experimental research, the mice were assigned to eight groups of eight each as follows: Normal saline receiving $(0.5 \mathrm{mg}) ; A$. atroviolaceum extract $(50,100$, and $200 \mathrm{mg} / \mathrm{kg}$ ) receiving groups; $A$. atroviolaceum extract $(50, \quad 100$, and $200 \mathrm{mg} / \mathrm{kg})+\mathrm{CP} \quad(6.1 \mathrm{mg} / \mathrm{kg})$ receiving groups; and CP $(6.1 \mathrm{mg} / \mathrm{kg})$ receiving group. All injections were performed intraperitoneally once a day for 30 days [25]. Eventually, mice were deep anesthetized by co-administration of ketamine $(60 \mathrm{mg} / \mathrm{kg}$, intraperitoneally) and xylazine $(10 \mathrm{mg} / \mathrm{kg}$, intraperitoneally) $[26,27]$ and then they euthanized. Finally, testes were dissected out and prepared for histopathological examinations [8].

\section{Measuring sperm parameters}

After the testicles and epididymes were removed, they were separated from each other. The epididymes were sliced and incubated in Ham's F10 at $37^{\circ} \mathrm{C}$ for 5 min to eliminate the sperm. The sperm count was calculated and the sperm motility was determined by hemocytometer using $5 \lambda$ of the sperm-containing media placed on neobar lam. The samples were analyzed using an optical microscope at $\times 40$ magnification, and 10 fields of lam were studied to calculate the sperm count and determine the sperm motility [15, 28, 29]. To evaluate the sperm count, sperm suspension was diluted in $3 \%$ normal saline in a proportion of $1-9$, and then a drop of the above solution using a micropipette was gently transferred to the neobar slide. After 5 min using a magnification of 40 spermatozoa with head, middle, and tail pieces were counted [8].

\section{Antioxidant capacity of $A$. atroviolaceum}

Fifty microliters of $A$. atroviolaceum extract was blended with $200 \mu \mathrm{L}$ of DPPH (2,2-diphenyl-1-picrylhydrazyl) solution in methanol. After $15 \mathrm{~min}$ at temperature of room, the absorbance was read at $517 \mathrm{~nm}$ using a UVVis spectrophotometer [30]. 
Total phenol and flavonoid content measurement

Aluminum chloride colorimetry and Rutin method was applied to measure the total flavonoids. Concentration levels of 25, 50, 100, 250, and $500 \mathrm{ppm}$ of standard solutions of Rutin in methanol were prepared. One milliliter from these solutions was moved into the tubes of test and blended with $1 \mathrm{~mL}$ of chloride aluminum $2 \%$. Six milliliters of potassium acetate $5 \%$ was added, and after $40 \mathrm{~min}$, the optical density level was recorded at $415 \mathrm{~nm}$ wavelength. Then, $0.01-0.02 \mathrm{~g}$ of the extracts was dissolved in methanol $60 \%$, reaching $10 \mathrm{~mL}$, and using chloride aluminum colorimetry, the total level of flavonoids was estimated. The total flavonoid level was determinded in milligram per $1 \mathrm{~g}$ extract, equivalent to Rutin [31].

The amount of total phenolic compounds was measured by colorimetric method using the Folin-Ciocalteu reagent. Five $\mathrm{mL}$ of extract or gallic acid (standard phenolic compound) was blended with Folin-Ciocalteu reagent (1:10 diluted with distilled water) and aqueous $\mathrm{Na}_{2} \mathrm{CO}_{3}(4 \mathrm{~mL}, 1 \mathrm{M})$. The mixtures were put it aside for $15 \mathrm{~min}$, and the total phenols were measured by colorimetry at $765 \mathrm{~nm}$. A standard curve get ready using $0,50,100,150,200$, and $250 \mathrm{mg} / \mathrm{L}$ solutions of gallic acid in methanol: water $(50: 50, \mathrm{vol} / \mathrm{vol})$. Total phenol values were stated in terms of gallic acid equivalent (in $\mathrm{mg} / \mathrm{g}$ ). The test was repeated in triplicate [32].

\section{Data analysis}

Data analysis was conducted by one-way ANOVA and Tukey's test in the Prism software version 5. Pearson's correlation coefficient was used to investigate correlation.

\section{Results}

Effect of $A$. atroviolaceum extract on count of sperm

The results exhibited a significant difference in sperm count between the groups $(p<0.001)$. The sperm count was significantly lower in the CP group than in the group of control $(p<0.001)$. In addition, the sperm count improved significantly in the $\mathrm{CP}+$ extract $(50,100$, and $200 \mathrm{mg} / \mathrm{kg}$ ) groups when compared to the CP group $(p<0.001, p<0.01)$. Sperm count was significantly greater in the extract (50, 100 , and $200 \mathrm{mg} / \mathrm{kg}$ ) groups than in the group of control $(p<0.001)$ (Fig. 1).

\section{Effect of $A$. atroviolaceum extract on sperm motility}

One-way ANOVA exhibited a significant difference in sperm motility among the groups $(p<0.001)$. The motility of sperm reduced significantly in the $\mathrm{CP}$ group when

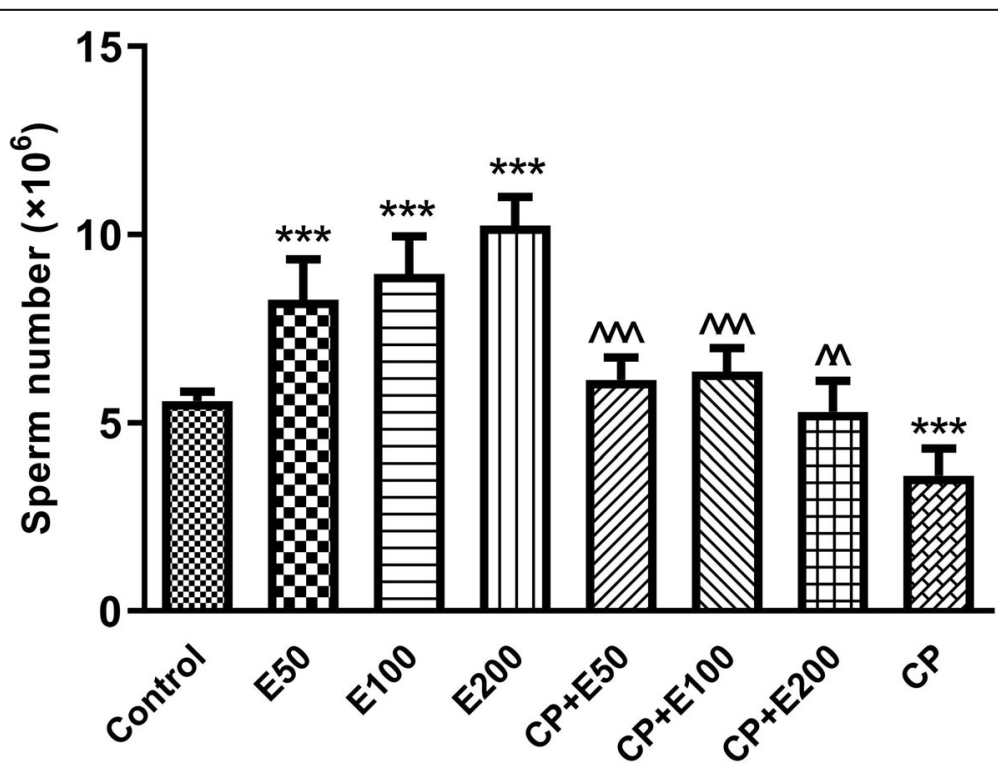

Exprimental groups

$$
\begin{aligned}
& { }^{* *} \mathrm{P}<0.001 \text {; compaired with control group } \\
& \wedge \wedge \mathrm{P}<0.01, \wedge \wedge \wedge \mathrm{P}<0.001 \text {; compaired with } \mathrm{CP} \text { group }
\end{aligned}
$$

Fig. 1 The effect of Allium atroviolaceum L. extract (E) on sperm count in cyclophosphamide (CP)-treated mice 
evaluated to the group of control $(p<0.001)$. Sperm motility was significantly higher in the extract $(100$ and $200 \mathrm{mg} / \mathrm{kg})$ groups than in the group of control $(p<0.05$ and $<0.001$, respectively). Sperm motility was also significantly greater in the $\mathrm{CP}+$ extract $(50,100$, and $200 \mathrm{mg} / \mathrm{kg})$ groups than in the $\mathrm{CP}$ group $(p<0.001)$ (Fig. 2$)$.

\section{Effect of $A$. atroviolaceum extract on sperm immotility and rotational movement}

The results showed a significant difference in sperm immotility between the groups $(p<0.001)$. The sperm immotility increased significantly in the CP group when compared to the group of control $(p<0.001)$. Besides that, sperm immotility decreased significantly in the $\mathrm{CP}+$ extract $(200 \mathrm{mg} / \mathrm{kg})$ group when evaluated to the group of control $(p<0.05)$. Sperm immotility was significantly higher in the $\mathrm{CP}$ group than in the $\mathrm{CP}+$ extract $(50,100$, and $200 \mathrm{mg} / \mathrm{kg})$ groups $(p<0.001)$ (Fig. 3). The results showed a significant difference in sperm rotational movement between the groups $(p<$ 0.001 ). The sperm rotational movement was significantly higher in the $\mathrm{CP}$ group than in the control group $(p<0.001)$. Besides that, the sperm rotational movement was significantly higher in the $\mathrm{CP}$ group than in the CP+extract $(50,100$, and $200 \mathrm{mg} / \mathrm{kg})$ groups $(p<0.001)$ (Fig. 4).
Effect of $A$. atroviolaceum extract on viability of sperm One-way ANOVA exhibited a significant difference in sperm viability among the groups $(p<0.001)$. The viability of sperm decreased significantly in the CP group when compared to the group of control $(p<0.001)$. The sperm viability was significantly higher in the $\mathrm{CP}+$ extract $(200 \mathrm{mg} / \mathrm{kg})$ group than in the CP group $(p<0.001)$. The sperm viability was also significantly higher in the extract (100 and $200 \mathrm{mg} / \mathrm{kg}$ ) groups than in the group of control $(p<0.01$ and $<0.001$, respectively) (Fig. 5).

\section{Effect of A. atroviolaceum extract on headless sperm count}

The results showed a significant difference in headless sperm count between the groups $(p<0.001)$. The headless sperm count was significantly higher in the $\mathrm{CP}$ group than in the of control $(p<0.001)$. Besides that, the headless sperm count was significantly lower in the $\mathrm{CP}+\mathrm{ex}$ tract $(50,100$, and $200 \mathrm{mg} / \mathrm{kg}$ ) groups than in the CP group $(p<0.05$ and $<0.001)$ (Fig. 6).

\section{Effect of $A$. atroviolaceum extract on a number of sperm with initial tail}

The results exhibited a significant difference in the number of the sperm with initial tail among the groups $(p<$ 0.001 ). The number of the sperm with initial tail was significantly higher in the $\mathrm{CP}$ group than in the group of

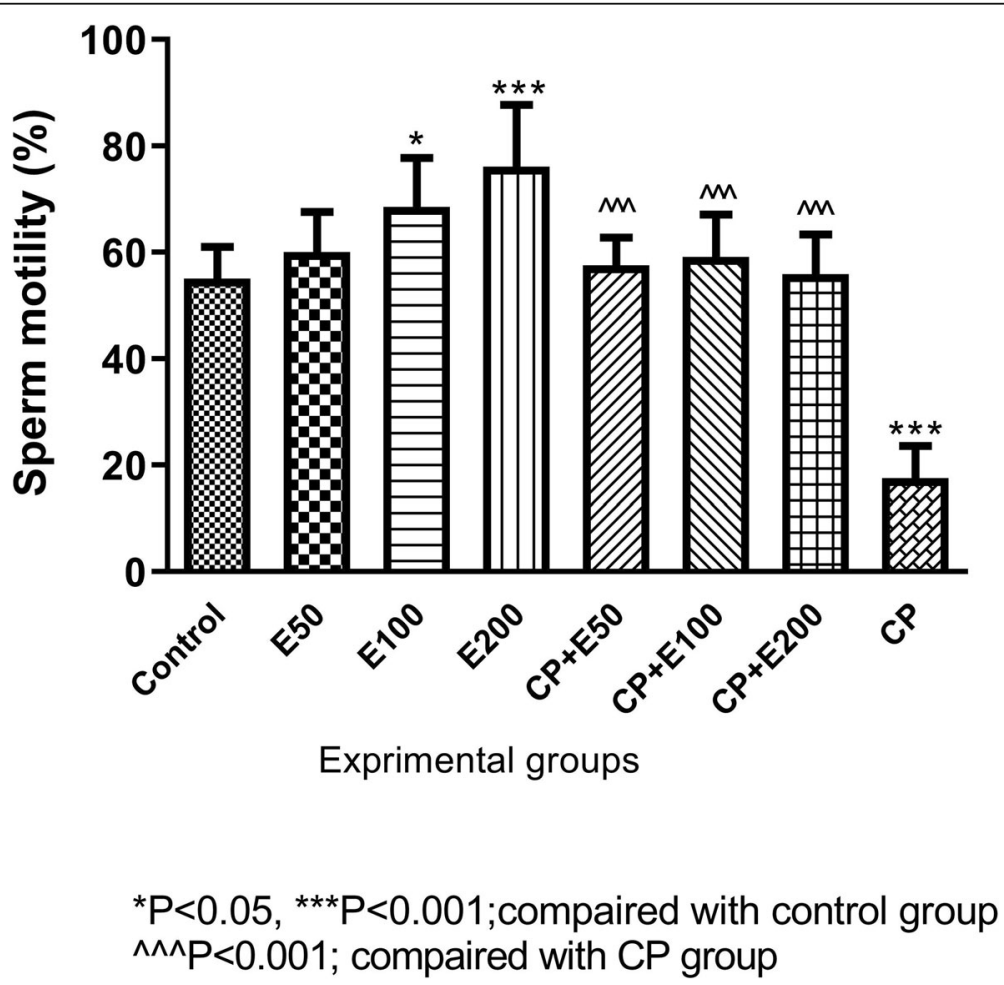

Fig. 2 The effect of Allium atroviolaceum L. extract (E) on sperm motility in cyclophosphamide (CP)-treated mice 


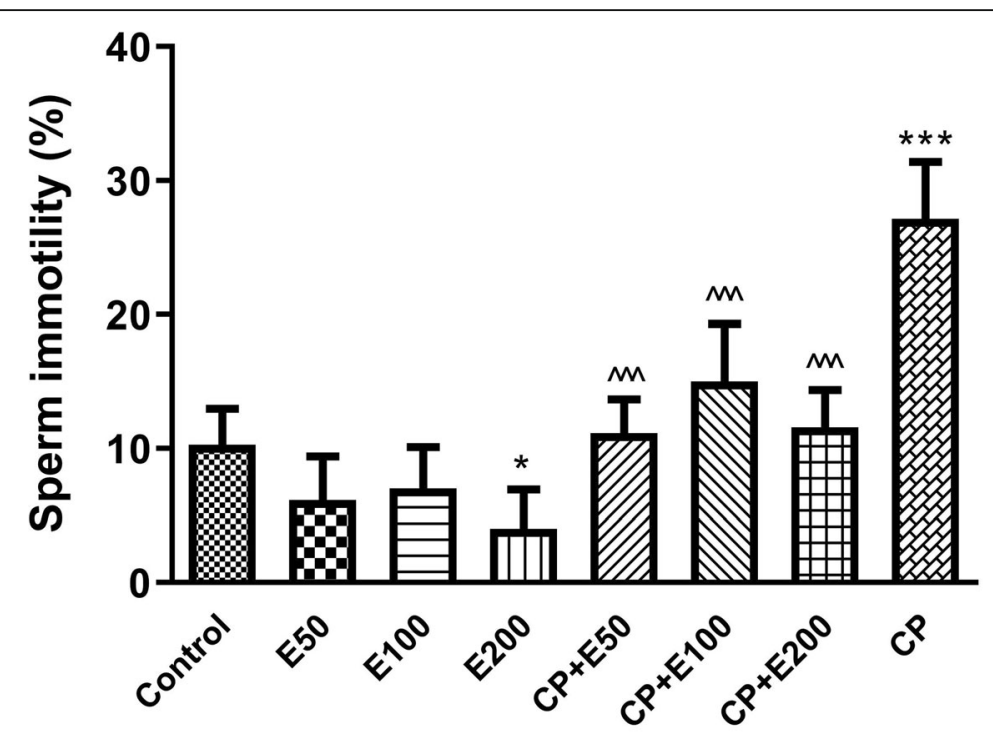

Exprimental groups

${ }^{*} \mathrm{P}<0.05,{ }^{* *} \mathrm{P}<0.001$; compaired with control group $\wedge \wedge \wedge P<0.001$, compaired with CP group

Fig. 3 The effect of Allium atroviolaceum L. extract (E) on sperm immotility in cyclophosphamide (CP)-treated mice

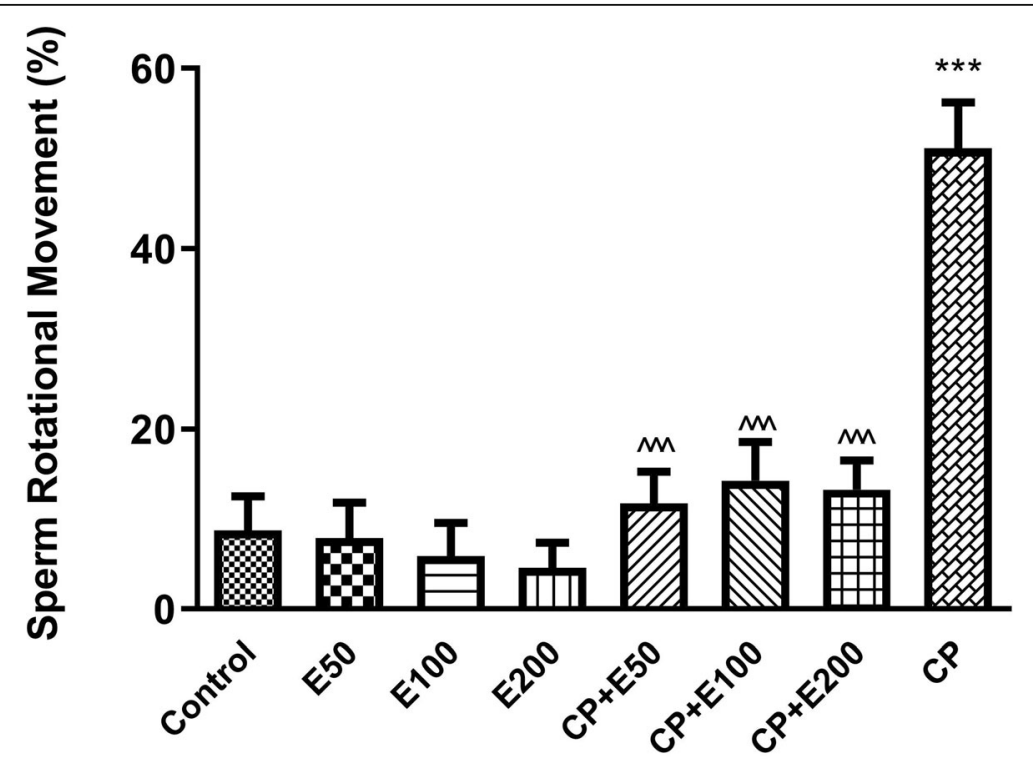

Exprimental groups

${ }^{* * *} \mathrm{P}<0.001$; compaired with control group $\wedge \wedge \wedge \mathrm{P}<0.001$; compaired with CP group 


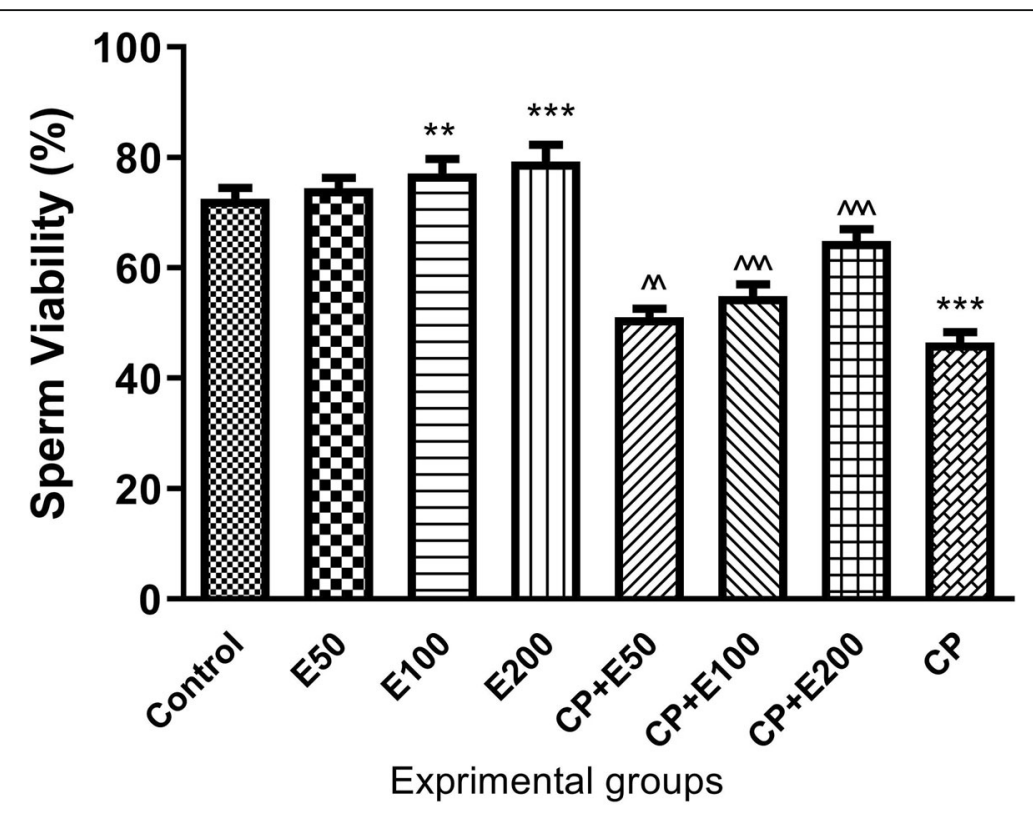

${ }^{* *} \mathrm{P}<0.01,{ }^{* * *} \mathrm{P}<0.001$; compaired with control group $\wedge \wedge \mathrm{P}<0.01,{ }^{\wedge \wedge \wedge} \mathrm{P}<0.001$; compaired with CP group

Fig. 5 The effect of Allium atroviolaceum L. extract (E) on sperm viability in cyclophosphamide (CP)-treated mice

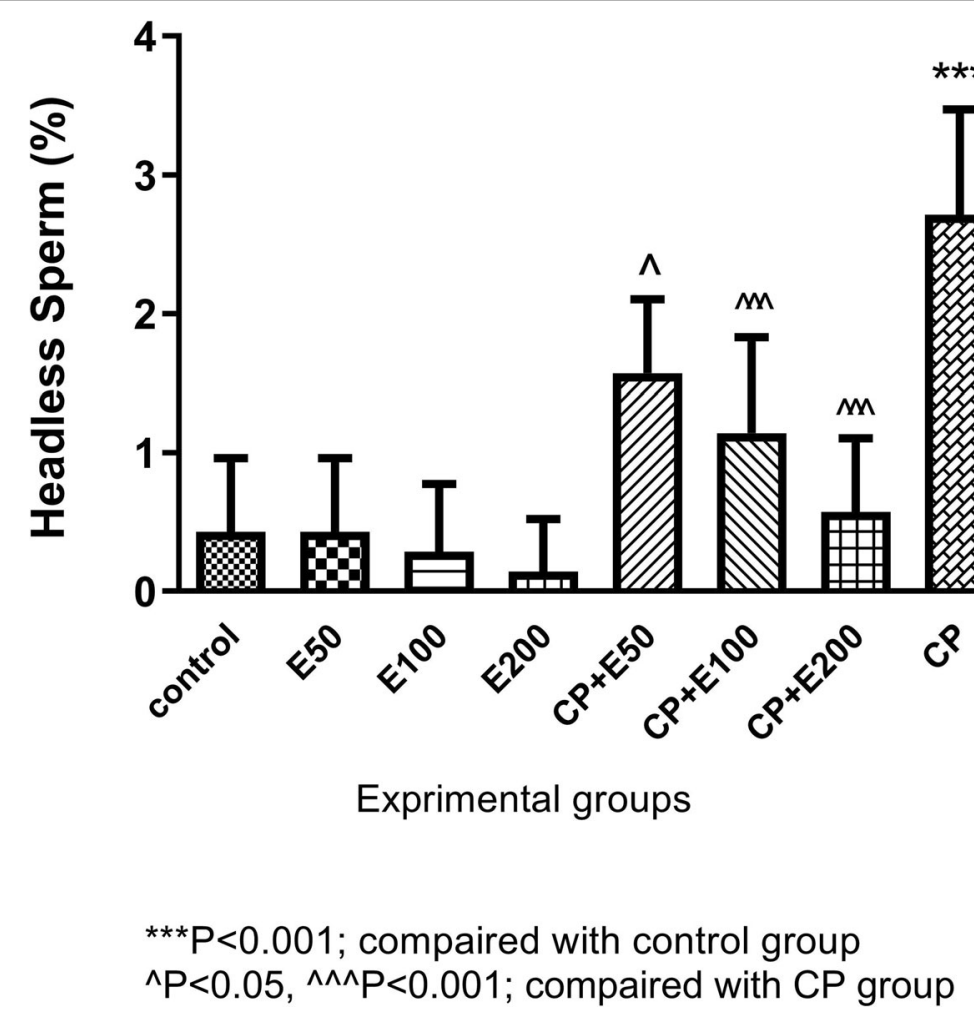

Fig. 6 The effect of Allium atroviolaceum L. extract (E) on headless sperm count in cyclophosphamide (CP)-treated mice 
control $(p<0.001)$. Besides that, the number of such sperm was significantly lower in the $\mathrm{CP}+$ extract $(100$ and $200 \mathrm{mg} / \mathrm{kg})$ groups than in the CP group $(p<0.005$ and $<0.001$, respectively) (Fig. 7 ).

\section{Effect of $A$. atroviolaceum extract on number of sperm} with coiled tail

One-way ANOVA exhibited a significant difference in the number of the sperm with dorsal tail among the groups $(p<0.001)$. The number of the sperm with coiled tail improved significantly in the $\mathrm{CP}$ group when evaluated to the group of control $(p<0.001)$. The number of the sperm with coiled tail was significantly lower in the $\mathrm{CP}+$ extract $(100$ and $200 \mathrm{mg} / \mathrm{kg}$ ) groups than in the CP group $(p<0.001)$ (Fig. 8$)$.

\section{Effect of A. atroviolaceum extract on number of sperm with curved body}

A significant difference in the number of the sperm with curved body was observed among the groups $(p<0.001)$. The number of the sperm with curved body improved significantly in the CP group when evaluated to the group of control $(p<0.001)$. Besides that, the number of such sperm was significantly lower in the CP+extract $(200 \mathrm{mg} / \mathrm{kg})$ group than in the CP group $(p<0.001)$ (Fig. 9).
Antioxidant capacity and total phenol and flavonoids content of $A$. atroviolaceum

Antioxidant capacity of $A$. atroviolaceum $L$. extract was measured as IC50 $=192.3 \pm 0.25 \mu \mathrm{g} / \mathrm{ml}$. Also total phenol and flavonoids content of this extract is $39.57 \mathrm{mg}$ equivalent rutin/gr dry weight of extract and $54.40 \mathrm{mg}$ equivalent galic acid per gr dry weight of extract, respectively.

\section{Discussion}

Impaired spermatogenesis is one of the most common causes of infertility in male. CP is one of the chemotherapy agents that are widely used to treat different types of cancers. Although $\mathrm{CP}$ has many clinical applications, it leads to adverse side effects such as reproductive toxicity in humans and animals [7]. Although the action mechanism of CP-induced testicular disorders has not yet been fully understood, studies have shown that CP can disrupt tissue regenerative. The resulting biochemical and physiological disorders are due to the excessive oxidative stress, and it is therefore necessary to use antioxidants throughout chemotherapy to reduce $\mathrm{CP}$-induced reduction of oxidative stress and to detoxify the tissues [33]. The current study was an investigation into the effects of hydroalcoholic $A$. atroviolaceum extract on spermatogenesis in CP-treated mice. Our results showed that the total count of sperm, count of motile sperm,

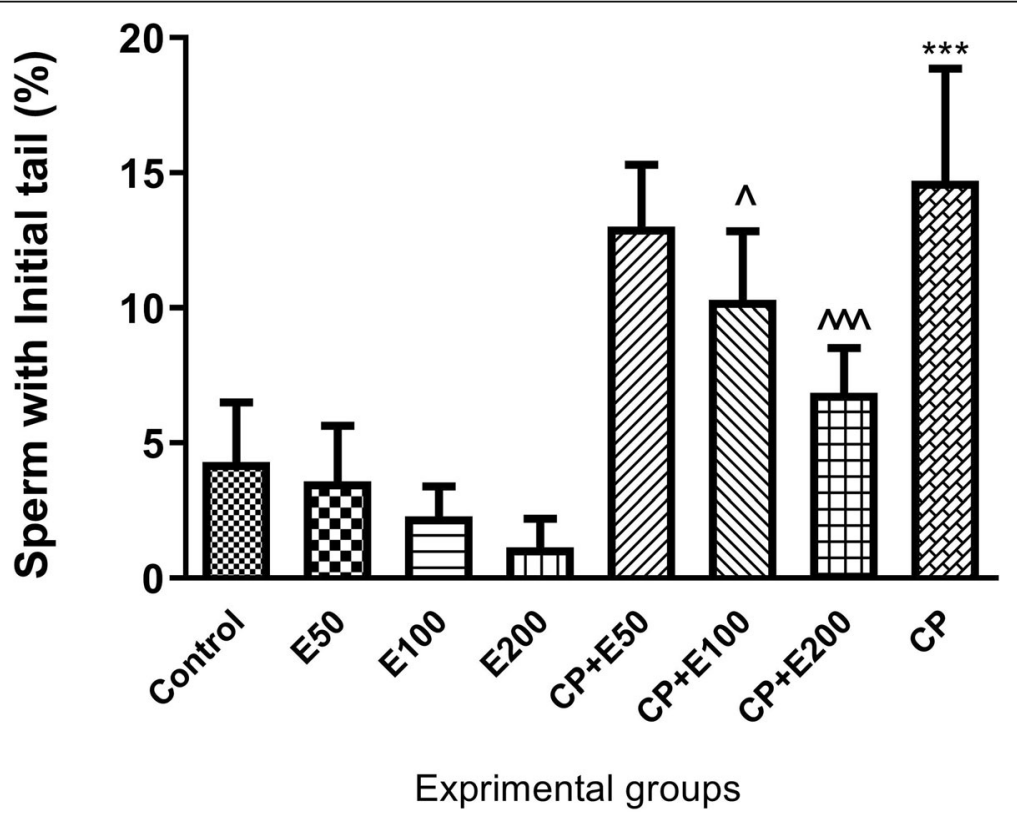

${ }^{* * *} \mathrm{P}<0.001$; compaired with control group ${ }^{\wedge} \mathrm{P}<0.05,{ }^{\wedge \wedge} \mathrm{P}<<0.001$; compaired with $\mathrm{CP}$ group

Fig. 7 The effect of Allium atroviolaceum L. extract (E) on the number of the sperm with initial tail in cyclophosphamide (CP)-treated mice 


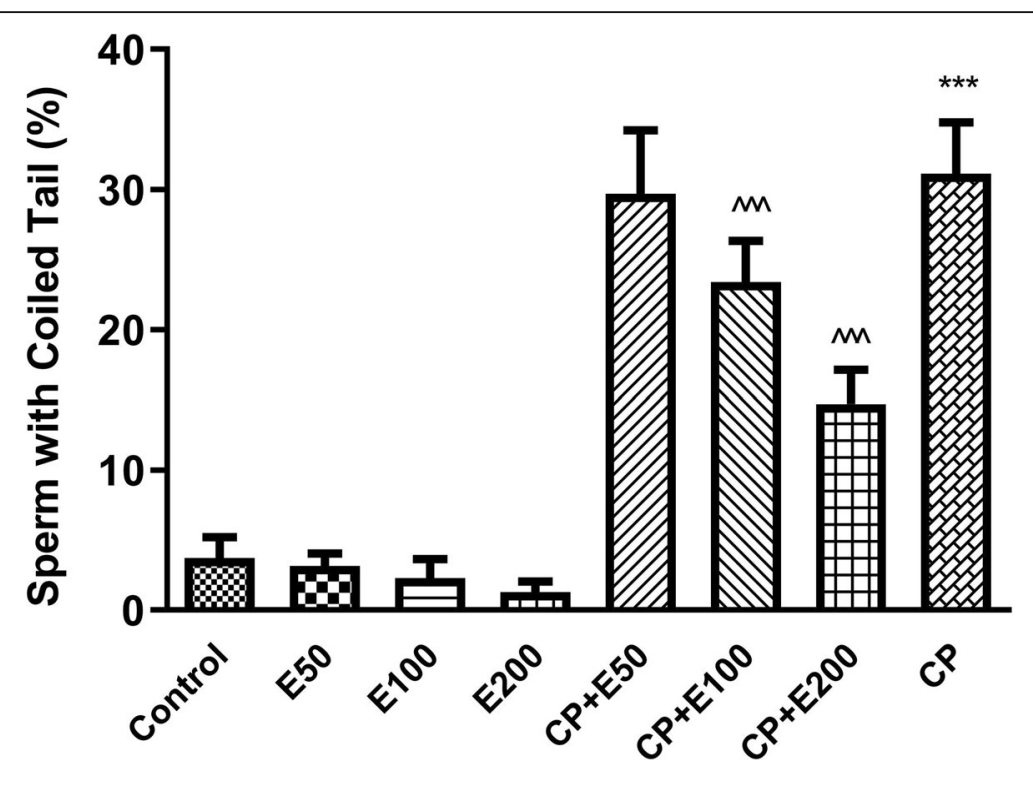

Exprimental groups

${ }^{* * *} \mathrm{P}<0.001$; compaired with control group

$\wedge \wedge \wedge \mathrm{P}<0.001$; compaired with CP group

Fig. 8 The effect of Allium atroviolaceum L. extract (E) on the number of the sperm with coiled tail count in cyclophosphamide (CP)-treated mice

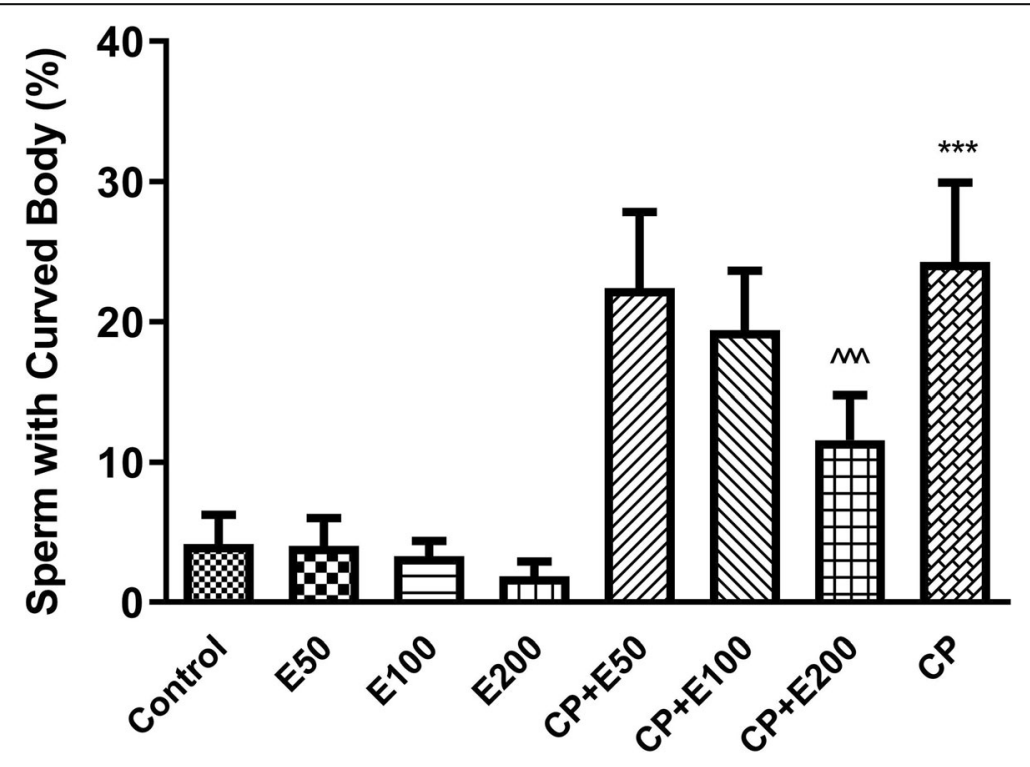

Exprimental groups

${ }^{* * *} \mathrm{P}<0.001$; compaired with control group ${ }^{\wedge \wedge \wedge} \mathrm{P}<0.001$; compaired with $\mathrm{CP}$ group 
and viability of sperm decreased significantly in the CPtreated mice when compared to the controls. In addition, the count of immotile sperm, the number of the sperm with rotational movement, the count of headless sperm, the quantity of the sperm with abnormal and dorsal tails, and the sperm with curved body was significantly greater in the $\mathrm{CP}$-treated group than in the group of control, reflecting the adverse effects of $\mathrm{CP}$ on spermatogenesis.

The adverse effects of $\mathrm{CP}$ on sperm morphology have been reported. The study of Buchanan et al. showed that spermatogenesis decreased significantly in the patients under $\mathrm{CP}$ treatment all of whom developed azoospermia after 6 months of CP treatment [34]. The study of Rezvanfar et al. also showed that CP caused impairment of spermatogenesis and fertility. Rezvanfar et al. observed that the sperm quality significantly declined in the CP-treated mice, which was associated with DNA damage and decline in chromatin quality [35]. Selvakumar et al. observed that the sperm count and motility decreased significantly and died and abnormal sperm count increased significantly in the CP-treated mice. Besides that, lipid peroxidation and protein carbonyl groups increased significantly in the epididymal sperm of the CP-treated mice [36]. The study of Çeribaşi et al. indicated that CP treatment was related with a significant improve in sperm tail and midpiece abnormalities in the mice [37], which is in agreement with the current study. We observed that treatment with $A$. atroviolaceum extract at different concentrations significantly increased the count of sperm, motility, and viability and significantly decreased the sperm immotility and rotational movement, the sperm with abnormal and dorsal tails as well as the sperm with curved midpiece. The doses of 50,100 , and $200 \mathrm{mg} / \mathrm{kg}$ of extract significantly improved the sperm motility, viability, and morphology when compared to the control group.

ROS play significant roles in sperm physiological processes such as capacitation, acrosome reactions, and sperm-oocyte binding, while the excessive production of ROS is associated, under certain conditions, with sperm DNA damage and decreased fertility [38]. In this condition, sperm during maturation lose a large proportion of their cytoplasm as residues and create cytoplasmic droplet in their bodies. The sperm containing these droplets have not fully matured and are still dysfunctional. The cytoplasmic residue contains large amounts of inner cytoplasmic and antioxidant enzymes. The lack of a large proportion of cytoplasm leads to decline in the antioxidant defense system. On the other hand, sperm is very disposed to oxidative stress because of large concentrations of unsaturated fatty acids in its plasma membrane and low concentrations of antioxidants. CP causes reproductive toxicity by increasing ROS and decreasing glutathione content and glutathione peroxidase (GPx) activity [33]. As an antioxidant agent, GPx contributes significantly to protecting the sperm in the testicular and epididymal tissues, and therefore, its reduction in the body leads to infertility. GPx protects sperm against free radicals and contributes to complete sperm maturation and evolution by staying on the sperm plasma membrane and nucleus and epididymal region and fluid [39]. The ability of $\mathrm{CP}$ to generate free radicals and to cause lipid peroxidation and oxidative stress in rats has been reported [35]. Cao et al. reported that CP caused decrease in the main enzymatic and non-enzymatic antioxidants in Leydig cells and thus decrease in testosterone synthesis and secretion through increasing oxidative stress, and acted as an effective factor for impairment of spermiogenesis and thus significant decrease in the epididymal sperm count [40]. The investigation of Aziz et al. confirmed that there was a significant association between the production of ROS in sperm and the proportion of the number of the sperm with abnormal morphology [41]. Given that A. atroviolaceum extract has exhibited activity of antioxidant in both in vitro and in vivo studies [42], it can be argued that this extract prevents sex cell damage by decreasing the levels of free radicals and ROS.

As far as we searched, no study has yet been conducted on the protective effects of $A$. atroviolaceum on the reproductive system but other species of the genus Allium have been investigated for such property. The study of Khaki et al. on Allium cepa effect on spermatogenesis in mice revealed that this plant caused increase in the sperm viability, motility, and count [4]. It has also been argued that the organic sulfur compounds present in the species from the genus Allium significantly decrease free radical-induced toxic effects on sperm DNA via increasing glutathione levels and GPx activity. Organic sulfur compounds increase the activities of GPx and superoxide dismutase in the liver, kidney, breast, and testicular cells and protect the cells by influencing peroxide forms and oxidative reduction [43].

\section{Conclusion}

Our results confirmed the protective effect of $A$. atroviolaceum extract against spermatogenesis in the CPtreated mice. With regard to the nutritional value of $A$. atroviolaceum, this plant can be used in the diets of the people who use CP to prevent or decrease its side effects. The properties of $A$. atroviolaceum extract, however, should be further studied with human subjects. 


\section{Abbreviations}

CP: Cyclophosphamide; A. atroviolaceum: Allium atroviolaceum

\author{
Acknowledgements \\ The authors gratefully thank the Research and Technology Deputy of \\ Shahrekord University of Medical Sciences (Grant no. 2259) and Medical \\ Plants Research Center of Shahrekord University of Medical Sciences for all \\ supports provided.
}

\section{Plant authentication}

The aerial parts of $A$. atroviolaceum were collected from Sabzkouh heights between late May 2013 and late June 2013. After identification by expert botanist (Shirmardi Hamzeh Ali, PhD., Research Center of Agriculture and Natural Resources, P.O. Box 415, Shahrekord, Iran), a specimen was deposited in herbarium at the Medical Plants Research Center, Shahrekord University of Medical Sciences, Shahrekord, Iran (Herbarium no.801).

\section{Authors' contributions}

ZLG and MSH conceptualized the project and gave technical inputs in conducting the study and preparing manuscript. AH, SHA, and NA performed the study and prepared manuscript. MA and AY gave technical inputs in conducting the study. ZLG and SHA analyzed the data. The authors have read and approved the manuscript.

\section{Funding}

This study was funded by the Research and Technology Deputy of Shahrekord University of Medical Sciences (Grant no: 2259). The funders have no role in the design of the study, data collection, analysis, interpretation of data, and in writing the manuscript.

\section{Availability of data and materials}

The datasets used and/or analyzed during the current study are available from the corresponding author on reasonable request.

\section{Declaration}

\section{Ethics approval and consent to participate}

All experimental procedures and protocols used in the study were reviewed and approved by the Shahrekord University of Medical Sciences ethical committee dated October 29, 2016. All applicable international, national, and/or institutional guidelines for the care and use of animals were followed. All stages of experimentation were carried out in accordance with the regulations of the University and the Guide for the Care and Use of Laboratory Animals of National Institutes of Health (Ethics code: IR.SKUMS.REC.1395.193),

\section{Consent for publication}

Not applicable.

\section{Competing interests}

The authors declare that they have no competing interests.

\section{Author details}

${ }^{1}$ Medical Plants Research Center, Basic Health Sciences Institute, Shahrekord University of Medical Sciences, Shahrekord, Iran. ${ }^{2}$ Department of Embryology and Histology, Faculty of Medicine, Shahrekord University of Medical Sciences, Shahrekord, Iran. ${ }^{3}$ Department of Anatomy and Neuroscience, Faculty of Medicine, Shahrekord University of Medical Sciences, Shahrekord, Iran.

\section{Received: 8 August 2020 Accepted: 24 March 2021} Published online: 01 April 2021

\section{References}

1. Speroff L, Glass R, Kase N (1999) Female infertility. Clinical Gynecologic Endocrinology and Infertility. Lippincott Williams \& Wilkins, Philadelphia

2. Estakhr J, Javdan N (2011) Spermatogenic activity of aloe vera in adult male rats. Pharmacologyonline 2:886-889

3. Omidbaigi R (2005) Production and processing of medicinal plants. Astan Godesa Razavei Publication, vol 1, p 346
4. KHAKI A, Nouri M, Fathi Azad F, Khaki AA (2008) Evaluation of Zingiber Officinalis and Allium Cepa on spermatogenesis in rat. Medicinal Journal of Tabriz university of medical sciences 30(2):53-58

5. Setiawan $L$ (1996) Tribulus terrestris $L$. extract improves spermatozoa motility and increases the efficiency of acrosome reaction in subjects diagnosed with oligoastheno-teratozoospermia. Advances in Male Reproductive Physiology 2:105-114

6. Zitzmann M (2008) Effects of testosterone replacement and its pharmacogenetics on physical performance and metabolism. Asian J Androl 10(3):364-372. https://doi.org/10.1111/j.1745-7262.2008.00405.x

7. Anderson D, Bishop J, Garner R, Wegman P, Selby P (1995) Cyclophosphamide: review of its mutagenicity for an assessment of potential germ cell risks. Mutat Res 330(1):115-181. https:/doi.org/10.1016/0027-5107(95)00039-L

8. Rostamzadeh A, Amini-khoei H, Mardani Korani MJ, Rahimi Madiseh M (2020) Comparison effects of olive leaf extract and oleuropein compounds on male reproductive function in cyclophosphamide exposed mice. Heliyon 6(4): e03785. https://doi.org/10.1016/j.heliyon.2020.e03785

9. Haque R, Hafeez B, Ahmad I, Parvez S, Pandey S, Raisuddin S (2001) Protective effects of Emblica officinalis Gaertn. in cyclophosphamide-treated mice. Hum Exp Toxicol 20(12):643-650. https://doi.org/10.1191/096032701718890568

10. Bahmani M, Sarrafchi A, Shirzad H, Rafieian M (2016) Autism: pathophysiology and promising herbal remedies. Curr Pharm Des 22(3): 277-285. https://doi.org/10.2174/1381612822666151112151529

11. Mirazi N, Rezaei M, Mirhoseini M (2016) Hypoglycemic effect of Satureja montanum L. hydroethanolic extract on diabetic rats. J HerbMed Pharmacol 5(1):17-22

12. Moshfegh F, Baharara J, Namavar F, Zafar-Balanezhad S, Amini E, Jafarzadeh L (2016) Effects of date palm pollen on fertility and development of reproductive system in female Balb/C mice. J Herbmed Pharmacol 5(1):23-28

13. Sedighi M, Bahmani M, Asgary S, Beyranvand F, Rafieian M (2017) A review of plant-based compounds and medicinal plants effective on atherosclerosis. J Res Med Sci 22:30

14. Sedighi M, Rafieian-Kopaei M, Noori-Ahmadabadi M (2012) Effect of Allium ampeloprasum on ileum function: involvement of beta-adrenergic receptors and voltage dependent calcium channels. Life Sci J 9(4):1660

15. Khaki A, Fathiazad F, Nouri M, Khaki AA, Khamenei HJ, Hamadeh M (2009) Evaluation of androgenic activity of allium cepa on spermatogenesis in the rat. Folia Morphol (Praha) 68(1):45-51

16. Lorigooini Z, Kobarfard F, Ayatollahi SA (2014) Anti-platelet aggregation assay and chemical composition of essential oil from Allium atroviolaceum Boiss growing in Iran. Int J Biosci 5(2):151-156

17. Khazaei S, Abdul Hamid R, Mohd Esa N, Ramachandran V, Tabatabaee F, Etamad A, Ismail P (2017) Promotion of HepG2 cell apoptosis by flower of Allium atroviolaceum and the mechanism of action. BMC Complement Altern Med 17(1):104. https://doi.org/10.1186/s12906-017-1594-6

18. Stajner D, Milić-DeMarino M, Canadanović-Brunet J (2003) Screening for antioxidant properties of leeks, Allium sphaerocephalon L. J Herbs Spices Med Plants 10(3):75-82

19. Bahmani M, Saatloo N, Gholami M, Karamati A, Banihabib E, Hajigholizadeh G, Borjian S (2013) A comparison study on the anti-leech effects of onion (Allium cepa $\mathrm{L}$ ) and ginger (Zingiber officinale) with levamisole and triclabendazole. J HerbMed Pharmacol 2(1):1-3

20. Rafieian-Kopaei M, Baradaran A, Rafieian M (2013) Oxidative stress and the paradoxical effects of antioxidants. J Res Med Sci 18(7):628

21. Lau B (1989) Detoxifying, radio-protective and phagocyte-enhancing effects of garlic. Int Clin Nutr Rev 9(1):27-31

22. Rafieian-kopaei M, Keshvari M, Asgari S, Salimi M, Heidarian E (2013) Potential role of a nutraceutical spice (Allium hirtifolium) in reduction of atherosclerotic plaques. J HerbMed Pharmacol 2(2):23-2823

23. Dehpour A, Babakhani B, Khazaei S, Asadi M (2011) Chemical composition of essential oil and antibacterial activity of extracts from flower of Allium atroviolaceum. J Med Plant Res 5(16):3667-3672

24. Noori-Ahmadabadi M (2013) Effect of hydro-alcoholic extract of Ziziphus Jujuba on the peripheral blood cells in Balb/c mice. J Physiol Pharmacol 17(2):224-230

25. Hosseini A, Zare S, Ghaderi Pakdel F, Ahmadi A (2010) Effects of vitamin E and Ginseng extract on fertility changes induced by cyclophosphamide in rats. J Reprod Infertil 11(4):227-237

26. Ghazvini H, Shabani M, Asadi M, Khalifeh S, Esmaeilpour K, Khodamoradi M, Sheibani V (2016) Estrogen and progesterone replacement therapy prevent methamphetamine-Induced synaptic plasticity impairment in ovariectomized rats. Addiction \& health 8(3):14527 
27. Amiri S, Alijanapour S, Tirgar F, Haj-mirzaian A, Amini-khoei H, Rahimi M, Rastegar M, Ghaderi M, Ghazi M, Zarrindast M (2016) NMDA receptors are involved in the antidepressant-like effects of capsaicin following amphetamine withdrawal in male mice. Neuroscience 329:122-133. https:// doi.org/10.1016/j.neuroscience.2016.05.003

28. Narayana K (2008) An aminoglycoside antibiotic gentamycin induces oxidative stress, reduces antioxidant reserve and impairs spermatogenesis in rats. J Toxicol Sci 33(1):85-96. https://doi.org/10.2131/jts.33.85

29. Khodamoradi K, Khosravizadeh Z, Amini-khoei A, Gilani MA, Mastalizadeh A, Kochakzadeh NS, Hassanzadeh G (2020) The association between toxic life stress and semen quality. J Sex Med 17(1):S90-S91. https://doi.org/10.1016/j. jsxm.2019.11.166

30. Rahnama S, Rabiei Z, Alibabaei Z, Mokhtari S, Rafiein-kopaei M, Deris F (2015) Anti-amnesic activity of Citrus aurantium flowers extract against scopolamine-induced memory impairments in rats. J Neurol Sci 36(4):553560. https://doi.org/10.1007/s10072-014-1991-2

31. Nasri H, Nematbakhsh M, Ghobadi S, Ansari R, Shahinfard N, Rafieian-kopaei M (2013) Preventive and curative effects of ginger extract against histopathologic changes of gentamicin-induced tubular toxicity in rats. Int J Prev Med 4(3):316-321

32. Bahmani M, Rafieian-kopaei M, Parsaei P, Mohsenzadegan A (2012) The antileech effect of Peganum harmala $L$. extract and some anti-parasite drugs on Limnatis nilotica. Afr J Microbiol Res 6(10):2586-2590

33. Ghalehkandi JG (2014) Garlic (Allium sativum) juice protects from semen oxidative stress in male rats exposed to chromium chloride. Anim Reprod Sci 11(4):526-532

34. Buchanan J, Fairley K, Barrie J (1975) Return of spermatogenesis after stopping cyclophosphamide therapy. The Lancet 306(7926):156-157. https://doi.org/10.1016/S0140-6736(75)90059-8

35. Rezvanfar M, Sadrkhanlou RA, Ahmadi A, Shojaei H, Rezvanfar MA, Mohammadirad A, Salehnia A, Abdollahi M (2008) Protection of cyclophosphamide-induced toxicity in reproductive tract histology, sperm characteristics, and DNA damage by an herbal source; evidence for role of free-radical toxic stress. Hum Exp Toxicol 27(12):901-910. https://doi.org/1 $0.1177 / 0960327108102046$

36. Selvakumar E, Prahalathan C, Sudharsan T, Varalakshmi P (2006) Chemoprotective effect of lipoic acid against cyclophosphamide-induced changes in the rat sperm. Toxicology 217(1):71-78. https://doi.org/10.1016/j. tox.2005.08.020

37. Çeribaşi AO, Türk G, Sönmez M, Sakin F, Ateşşahin A (2010) Toxic effect of cyclophosphamide on sperm morphology, testicular histology and blood oxidant-antioxidant balance, and protective roles of lycopene and ellagic acid. Basic Clin Pharmacol Toxicol 107(3):730-736. https://doi.org/10.1111/j.1 742-7843.2010.00571.x

38. Khodamoradi K, Amini-khoei H, Khosravizadeh Z, Hosseini SR, Dehpour AR, Hassanzadeh GH (2019) Oxidative stress, inflammatory reactions and apoptosis mediated the negative effect of chronic stress induced by maternal separation on the reproductive system in male mice. Reprod Biol 19(4):340 348. https://doi.org/10.1016/j.repbio.2019.10.003

39. Su D, Novoselov S, Sun Q, Mustafa M, Zhou Y, Oko R, Hatfiield D, Gladyshev $\checkmark$ (2005) Mammalian selenoprotein thioredoxin-glutathione reductase roles in disulfide bond formation and sperm maturation. J Biol Chem 280(28): 26491-26498. https://doi.org/10.1074/jbc.M503638200

40. Cao L, Leers-Sucheta S, Azhar S (2004) Aging alters the functional expression of enzymatic and non-enzymatic anti-oxidant defense systems in testicular rat Leydig cells. J Steroid Biochem Mol Biol 88(1):61-67. https:// doi.org/10.1016/j.jsbmb.2003.10.007

41. Aziz N, Saleh R, Sharma R, Lewis-Jones I, Esfandiari N, Thomas A, Agarwal A (2004) Novel association between sperm reactive oxygen species production, sperm morphological defects, and the sperm deformity index. Fertil Steril 81(2):349-354. https://doi.org/10.1016/j.fertnstert.2003.06.026

42. Štajner D, Popović BM (2009) Comparative study of antioxidant capacity in organs of different Allium species. Cent Eur J Biol 4(2):224-228

43. Pedraza-Chaverrí J, Maldonado P, Medina-Campus O, Olivares IM, Silvestre M, Hernandez R, Rubio M (2000) Garlic ameliorates gentamicin nephrotoxicity: relation to antioxidant enzymes. Free Radical Biology and Medicine 29(7): 602-611, DOl: https://doi.org/10.1016/S0891-5849(00)00354-3

\section{Publisher's Note}

Springer Nature remains neutral with regard to jurisdictional claims in published maps and institutional affiliations.

\section{Submit your manuscript to a SpringerOpen ${ }^{\circ}$ journal and benefit from:}

- Convenient online submission

- Rigorous peer review

- Open access: articles freely available online

- High visibility within the field

- Retaining the copyright to your article

Submit your next manuscript at $\boldsymbol{\nabla}$ springeropen.com 